\title{
PERLINDUNGAN HUKUM KONSUMEN PENGGUNA KOSMETIK TANPA IZIN EDAR DALAM PERSPEKTIF UNDANG-UNDANG NOMOR 8 TAHUN 1999 TENTANG PERLINDUNGAN KONSUMEN
}

\author{
Oleh: \\ Indah Dwi Rahmawati** \\ I Made Udiana*** \\ I Nyoman Mudana*** \\ Bagian Hukum Bisnis \\ Fakultas Hukum Universitas Udayana
}

ABSTRAK

Perlindungan terhadap konsumen di Indonesia ditetapkan oleh pemerintah dalam Undang-Undang Nomor 8 Tahun 1999 Tentang Perlindungan Konsumen. Di Indonesia terdapat banyak pelanggaran terhadap beberapa hak konsumen dalam produksi kosmetika yang diproduksi atau diedarkan oleh pelaku usaha yang melanggar peraturan Perundang-Undangan, baik peraturan didalam Undang Undang Perlindungan Konsumen maupun peraturan yang telah ditetapkan oleh kepala BPOM. Apabila konsumen tidak teliti dalam memilih produk atau barang yang diinginkan maka konsumen akan menjadi sarana objek dalam mendapatkan keuntungan oleh pelaku usaha kosmetika. Pentingnya penulisan ini adalah untuk mengetahui perlindungan hukum yang dapat diperoleh oleh konsumen yang dirugikan

Penelitian hukum normatif yang menggunakan pendekatan Perundang-Undangan. Sumber data yang dipergunakan berasal dari hasil data primer bersumber dari Peraturan Undang-Undang dan data sekunder bersumber dari kepustakaan.

Dari hasil penelitian ini disimpulkan bahwa konsumen yang telah melaksanakan kewajibannya untuk berhati-hati dalam memilih produk akan mendapatkan perlindungan hukum dan berhak mengajukan upaya hukum, sebaliknya yang tidak berhati hati dalam memilih produk tidak berhak mendapatkan perlindungan hukum berupa ganti kerugian yang diberikan oleh pelaku usaha. Peran pemerintah sangat dibutuhkan untuk memberikan edukasi kepada konsumen terkait produk kosmetik sesuai dengan aturan yang ada. 


\title{
Kata kunci: Perlindungan hukum konsumen, Konsumen, Pelaku usaha, Kosmetika
}

\author{
*makalah ini merupakan inti sari dari skripsi \\ **Indah Dwi Rahmawati adalah mahasiswa Fakultas Hukum Universitas \\ Udayana, Korespondensi indahdwi_rahmawati@yahoo.com \\ ***I Made Udiana adalah Dosen Fakultas Hukum Universitas Udayana. \\ ***I Nyoman Mudana adalah dosen Fakultas Hukum Universitas Udayana.
}

\begin{abstract}
Legal protection for consumers in Indonesia has a legal basis set by the government. Violations of rights to consumers in the production of cosmetics produced by business actors who consumer rights. If you are not careful in choosing the desired item or product, the consumer will only be the object to obtain profits by irresponsible business actors. The importance of this writing is to find the legal protect obtained by consumers who experience losses.

Normative legal research that uses the Legislation approach. The source of data used in this study comes from the results of primary data sourced from Legislation sourced from literature.

Consumers who have carried out their obligations to be careful in choosing a product will get legal protection and have the right to file legal remedies, whereas those who are not careful in choosing a product are not entitled to legal protection in the form of compensation given by a business actor. The role of government is needed to educate consumers regarding cosmetic products that are in accordance with prevailing laws and regulations.
\end{abstract}

\section{Keywords: Consumer Legal Protection, Consumer, Bussines Actors, Cosmetics \\ I. PENDAHULUAN}

\section{$1.1 \quad$ Latar Belakang}

Jumlah Konsumen dan skala keberadaannya yang sangat tidak terbatas dan bervariasi menyebabkan produsen 
melakukan kegiatan distribusi barang dan/jasa dengan sangat efektif agar mencapai konsumen yang majemuk. Oleh karena itu mendorong produsen untuk melakukan kegiatasn atau pengadaan barang dengan tidak sesuai pada prosedur sehingga berpotensi untuk melakukan kegiatan penjualan yang akan berdampak negatif bahkan tidak terpuji dengan awal untuk beritikad baik, dampak tersebut antara lain terkait mutu barang, kondisi barang dan/jasa, informasi yang tidak jelas bahkan sampai kepada pemalsuan. ${ }^{1}$

Pada era perdagangan bebas sekarang begitu banyak beredar produk kosmetika yang tidak memili izin edar beredar secara bebas di pasaran.Sekalipun bahaya bagi kesehatan kosmetika tersebut begitu mudah didapatkan dengan harga yang murah. Namun bahaya dari penggunaan tersebut oleh beberapa konsumen sering diabaikan demi mendapatkan harga yang relatif lebih murah.Tanpa disadari dalam penggunaan jangka panjang kosmetik tersebut dapat memberikan dampak negatif bagi konsumen, contohnya kerusakan pada wajah atau berkurangnya fungsi organ di dalam tubuh.

Tercantum pada Undang-Undang Nomor 36 Tahun 2009 Tentang Kesehatan Pasal 105 ayat 2 menentukan "Sediaan Farmasi berupa obat tradisional dan kosmetika serta alat kesehatan harus memenuhi standar dan/atau persyaratan yang ditentukan". Selanjutnya dalam Pasal 106 ayat 1 menentukan "Sediaan farmasi dan alat kesehatan hanya dapat diedarkan setelah mendapat izin edar"

${ }^{1}$ Celina Tri siwi Kristiyanti, 2011, Hukum Perlindungan Konsumen, Sinar Grafika, Jakarta, h.5. 
Berkaitan dengan ketentuan pada Undang-Undang Kesehatan tersebut mengenai kosmetik harus memperoleh izin edar maka segala hubungan hukum yang dilakukan oleh konsumen dan produsen kosmetik dalam transaksi jual beli kosmetik harus dilindungi. Sedangkan di dalam UUPK) yang masih memiliki kekurangan dalam ruang lingkupnya, dimana didalam UUPK Pasal 8 ayat 3 hanya mengatur tentang larangan bagi pelaku usaha memperdagangkan sediaan farmasi dan pangan rusak, cacat dan tercemar, dengan atau tanpa memberikan informasi dengan benar. Dalam Pasal tersebut hanya menentukan bahwa pelaku usaha tidak diperbolehkan memperdagangkan sediaan farmasi yang rusak, caca dan atau bekas atau sediaan farmasi tanpa izin edar.Dengan adanya kekosongan norma tersebut maka upaya dalam hal perlindungan terhadap konsumen belum maksimal, dengan begitu akan semakin memperluas ruang gerak pelaku usaha untuk memproduksi sediaan farmasi yang berupa kosmetika dengan tanpa adanya izin edar.

Salah satu konsideran UUPK isu perlindungan konsumen merupakan suatu halyang ada keterkaitanekspansi dunia usaha yang mengglobal. ${ }^{2}$

\subsection{Rumusan Masalah}

Sesuai dengan latar belakang yang telah diuraikan, maka dapat ditarik permasalahan sebagai berikut:

2 Ali Mansyur,Irsan Rahman, Penegakkan Hukum Perlindungan Konsumen Sebagai Upaya Peningkatan Mutu Produksi Nasional, Jurnal Penelitian Universitas Islam Sultan Agung, Volume 11 Nomor 1 Januari-April Tahun 2015, URL:https//online-jurnalunisulla.ac.id, diakses tanggal 31 Maret 2019 
1. Apakah konsumen yang mengalami kerugian akibat mengguanakan kosmetik tanpa izin edar mendapatkan perlindungan hukum konsumen?

2. Upaya hukum apa yang dapat dilakukan oleh konsumen yang mengalami kerugian akibat menggunakan kosmetik tanpa izin edar?

\subsection{Tujuan}

Tujuan penelitian ini untuk mengetahui bentuk perlindungan hukum yang diterima oleh konsumen yang mengalami kerugian dan untuk mengetahui apa saja upaya hukum yang dapat ditempuh oleh kosumen yang dirugikan akibat menggunakan kosmetik tanpa izin edar

\section{ISI MAKALAH}

\subsection{Metode Penelitian}

Penelitian yang digunakan oleh penulis dalam penulisan penelitian ini adalah penelitian hukum normatif yang mengacu pada adanya peraturan dengan jenis penelitian yang digunakan yakni penelitian hukum normatif dengan menggunakan pendekatan Undang-Undang (Statue approach).. Menurut Soerjono Soekanto, "pendekatan kualitatif adalah cara penelitian yang menghasilkan deskriptif analisis yaitu apa yang dinyatakan oleh responden secara tertulis atau lisan dan juga perlakuannya yang nyata diteliti dan dipelajari sebagai suatu kesatuan yang utuh"3

${ }^{3}$ Soerjono Soekanto, 2010, Pengantar Penelitian Hukum, UI Press, Jakarta, h. 5. 


\subsection{Hasil Dan Analisis}

\subsubsection{Perlindungan Hukum Konsumen Yang Mengalami Kerugian Akibat Menggunakan Kosmetik Tanpa Izin Edar}

Perlindungan hukum bagi konsumen di Indonesia diatur dalam ketentuan Perundang-Undangan yaitu Undang-Undang Nomor 8 Tahun 1999 tentang Perlindungan Konsumen (selanjutnya disebut UUPK). ${ }^{4}$

Didalam buku Andrian Sutedi tentang tanggung jawab produk yang tertera di dalam hukum Perlindungan Konsumen, disebutkan:

1. Berhak mendapat barang dengan kualitas dan kuantitas yang baik dan aman. Dengan adanya hak ini sudah sangat jelas bahwa konsumen wajib dilindungi haknya untuk mendapatkan barang yang bermutu. Kurangnya pengetahuan konsumen terhadap produk yang dibeli sering kali menjadi akses bagi produsen untuk memperdayakannya, konsumen tidak jarang disudutkan pada kondisi "jika anda beli silahkan, jika tidak membeli silahkan ditempat lain" dalam kondisi yang seperti ini konsumen cenderung mencari produk yang kualitasnya lebih buruk

2. hak untuk mendapatkan ganti kerugian

$4 \quad \mathrm{Ni}$ Putu Januaryanti Pande, "Perlindungan Konsumen Terhadap Produk Kosmetik Impor Yang Tidak Terdaftar", jurnal Magister Hukum Udayana, $\begin{array}{llllll}\text { Volume } & 6 & \text { Nomor } & 1 & \text { Tahun }\end{array}$ URL:https://ojs.unud.ac.id/index.php/jmhu/article , diakses pada tanggal 10 April 2019,h.14. 
Jika produk yang telah dibeli dirasa cacat, rusak, atau telah membahayakan dirinya setelah digunakan ia memiliki hak atas mendapatkan ganti kerugian, namun jenis ganti rugi yang diklaim harus sesuai dengan kesepakatan dari pada pihak, artinya konsumen tidak dapat menuntut berlebihan dari barang yang dibelinya dengan harga yang dibayarnya, kecuali barang yang digunakan tersebut menimbulkan gangguan pada tubuh atau mengakibatkan cacat pada tubuh konsumen, maka tuntutan konsumen dapat melebihi dari harga barang yang dibelinya. ${ }^{5}$

Berdasarkan tinjauan teori kontrak dan Due Care Teory dalam menaggapi beberapa kasus peredaran produk tanpa izin edar bisa disimpulkan, konsumen harus berhati-hati sebelum melakukan pembelian, bisa memahami karakteristik produk dan tidak mengabaikan tulisan-tulisan penjelasan dalam bungkus maupun buku manual yang ada dalam produk

Secara garis besar menurut Hanz.W.Milkitz dapat dibedakan ada dua tipe konsumen yaitu:

1. Konsumen yang terinformasi (well informed) adapun cirri-ciri konsumen ini adalah::

a. Mempunyai tingkat pendidikan tertentu;

b. Memiliki sumber daya ekonomi yang cukup, sehingga dengan begitu mampu memiliki dalam ekonomi pasar bebas;

c. Lancar dalam berkomunikasi.

2. Konsumen yang tidak terinformasi yang memiliki ciri-ciri:

a. Memiliki pendidikan yang kurang;

${ }^{5}$ Gunawan Widjaja, Ahmad Yani, 2000, "Hukum Perlindungan Konsumen", Gramedia Pustaka Utama, Jakarta, h.59. 
b. Tergolong kedalam ekonomi kelas ke bawah;

c. Tidak lancar dalam berkomunikasi. ${ }^{6}$

Menurut hemat saya sehubungan dengan pendapat tersebut beberapa konsumen yang sudah berhati hati dalam memilih kosmetik tanpa izin edar namun kemudian dirugikan dikategorikan kedalam jenis konsumen yang tidak terinformasi, karena tingkat pendidikannya yang rendah dan kelas ekonomi ke bawah sehingga dalam memilih dia tidak memahami bahwa kosmetik yang dibelinya tersebut harus memiliki izin edar. Dan tipe konsumen seperti ini berhak mendapat perlindungan hukum konsumen apabila sudah mengalami kerugian berupa rusak di wajah atau bahkan sampai kepada cacat fisik berupa ganti rugi yang harus diberikan oleh produsen.

Kemudian terkait mengenai konsumen kosmetika yang tidak berhati-hati dalam memilih kosmetik yang pada dasarnya dia sudah mengetahui bahwa kosmetik tersebut seharusnya memiliki izin edar namun dia tetap membelinya dikarenakan faktor harga yang relatif jauh lebih murah maka konsumen tersebut tidak berhak mendapat perlindungan hukum konsumen.Karena konsumen tidak memenuhi kewajibannya sesuai dengan ketentuan Pasal 5 huruf a UUPK. Dalam kaitannya dengan hak-hak untuk konsumen pengguna kosmetik tanpa izin yang mengalami kerugian setelah mengkonsumsi kosmetik tersebut dapat sepenuhnya diterima oleh konsumen apabila konsumen pengguna kosmetik tanpa izin edar tersebut telah memenuhi

6Sidhiarta, 2004, Hukum Perlindungan Konsumen Indonesia, Jakarta, PT.Grasindo Edisi Revisi, h.3 
kewajibannya untuk berhati-hati dalam memilih produk kosmetik.

\subsubsection{Upaya Hukum Yang Dapat Dilakukan Oleh Konsumen Yang Mengalami Kerugian Akibat Menggunakan Kosmetik Tanpa Izin Edar}

Konsumen pengguna kosmetik yang merasa dirugikan menggunakan akibat menggunakan kosmetik yang tidak memiliki izin edar berhak membela hak nya dengan melakukan upaya hukum yang telah diatur oleh pemerintah di dalam Undang-Undang, Adapun dua upaya hukum yang dapat ditempuh antara lain litigasi dan non litigasi. Dalam hal upaya penyelesaian sengketa melalui litigasi pemerintah membentuk suatu badan, yaitu BPSK. Dalam hal penyelesaian sengketa konsumen diluar pengadilan. Dalam Pasal 52 huruf a UndangUndang Perlindungan Konsumen penyelesaian sengketa konsumen melalui BPSK yaitu dengan cara mediasi, arbitrase dan konsiliasi. Pada Undang-Undang Nomor 30 Tahun 1999 tentang Arbitrase dan Alternatif Penyelesaian Sengketa, ditentukan bahwa sengketa perdata dapat diselesaikan oleh para pihak melalui alternatif penyelesaian segketa yang berdasarkan pada iktikad baik dengan tidak mendahulukan dalam hal menyelasaikan sengketa secara litigasi di Pengadilan Negeri. ${ }^{7}$

Pada prinsipnya penyeselesaian sengketa yang diselenggarakan di BPSK hanya untuk menentukan besar ganti kerugian yang diterima oleh konsumen yang mengalami kerugian, selain itu untuk mencapai kesepakatan agar hal

7I Made Widnyana, 2014, Alternatif Penyelesaian Sengketa dan Arbitrase, PT. Fikahati Aneska, Jakarta, h.71. 
serupa tidak terulang kembali yang tertuang dalam bentuk jaminan berupa jaminan tertulis. Ukuran kerugian materi yang diperoleh konsumen sesuai dengan penggunaan barang dan/jasa yang merugikan setelah diproduksi.

Adapun cara dalam menyelesaikan sengketa antara konsumen dan produsen oleh BPSK terdapat dalam Kepmenperindag NO.350-/MPP/12/-2001 tentang Pelaksanaan Tugas dan Wewenang BPSK. Proses penyelesaian pun diatur dengan sangat sederhana dan sejauh mungkin dihindari suasana yang formal.

Di dalam UUPK menetukan bahwa apabila upaya dalam menyelesaikan sengketa di luar tidak memperoleh kesepakatan abtara kedua belah pihak maka gugatan melalui pengadilan dapat ditempuh. Adapun beberapa tahap yang dilakukan, antara lain
a. Tahap Pengajuan gugatan;
b. Tahap Persidangan;
c. Tahap Putusan.

Adapun cara dalam tahap persidangan, yaitu persidangan dengan cara mediasi, persidangan dengan cara konsiliasi dan persidangan dengan cara arbitrase. Adapun salah satu cara dari beberapa cara persidangan dalam BPSK tersebut adalah sesuai dengan keinginan pihak yang terlibat dalam sengketa untuk memilih salah satu cara persidangan yang akan digunakan.

Adapun pada tahap putusan setelah melalui tahap persidangan dan pemeriksaan maka putusan dapat disepakati oleh kedua belah pihak atau tidak, dalam hal tidak disepakatinya putusan hakim maka para pihak yang berperkara dapat mengajukan gugatan melalui pengadilan dan berproses acara 
sesuai dengan prosedur persidangan di dalah hukum acara perdata.

Dalam Pasal 19 Ayat 1 UUPK mengatur bahwa ganti kerugian yang dibebankan kepada pelaku usaha adalah sesuai dengan kerugian, kerusakan, atau pencemaran yang diderita oleh konsumen setelah menggunakan kosmetik tanpa izin edar yang beredar ilegal.Pasal 19 Ayat 2 UUPK mengatur bahwa ganti kerugian sebgaimana dimaksud adalah ganti kerugianberupa pengembalian uang atau barangyang sejenis atau setara nilainya, pemberian santunan, atau penggantian kerugian terhadap keuntungan yang harusnya didapat oleh konsumen.

Di dalam UUPK tidak hanya mengatur mengeai sanksi berupa ganti rugi, namun juga sanksi administrative kerugian paling banyak Rp.200.00 (dua ratus juta rupiah). Sanksi administratif dibebani kepada produsen yang tidak berkendak dalam bertanggung jawab..

Selain penyelesaian sengketa melalui BPSK, pemerintah juga menyediakan BPOM untuk menyelesaikan sengketa konsumen, dapat berupa pengaduan ataupun laporan. BPOM menyediakan Unit Layanan Pengaduan Konsumen, yang dimana tugasnya melayani konsumen atau masyarakat yang memiliki aduan tentang, makanan dan nimuman, obat obatan tradisional, kosmetika dan alat-alat kesehatan.

Proses lain oleh pemerintah untuk penyelesaian sengketa konsumen adalah melalui peradilan umum. Sengketa bisnis yang bisa diajukan ke Peradilan Umum, antara lain sengketa yang terjadi karena wanprestasi (ingkar janji) dan perbuatan melawan hukum (dalam konteks hukum perdata) yang menyebabkan 
kerugian salah satu pihak atau kedua pihak ${ }^{8}$ Sengketa bisnis yang bisa diajukan ke Peradilan Umum, antara lain sengketa yang terjadi karena wanprestasi (ingkar janji) dan perbuatan melawan hukum (dalam konteks hukum perdata) yang menyebabkan kerugian salah satu pihak atau kedua pihak ${ }^{9}$

\section{PENUTUP}

\subsection{Kesimpulan}

Sesuai dengan pembahasan penelitian sebagaimana telah diuraikan di atas, dapat ditarik kesimpulan antara lain:

3.1.1 Perlindungan hukum konsumen bagi pengguna kosmetik yang mengalami kerugian berupa kerusakan pada bagian wajah, atau organ tubuh lainnya akibat mengkonsumsi kosmetik tanpa izin edar akan mendapat perlindungan hukum yang berupa ganti kerugian oleh pelaku usaha apabila konsumen tersebut telah memenuhi kewajibannya untuk berhati-hati dan teliti dalam membeli kosmetik, memeriksa label pada kemasan, komposisi, tanggal kaduwarsa, dan nomor teregistrasi BPOM.Sebaliknya apabila konsumen tidak memenuhi kewajibannya dalam memilih produk kosmetik dengan tidak memeriksa label atau nomor registrasi BPOM maka konsumen tersebut tidak berhak mendapatkan perlindungan hukum berupa ganti rugi.

8 Novitasari, "Tinjauan Yuridis Pembatasan Jangka Waktu Penundaan Kewajiban Pembayaran Utang Terhadap Debitor", jurnal Magister Hukum Udayana, Volume 39. Nomor 2 Agustus 2017, URL:https//doi.org/1024843/KP2017.v39.i02.p02, diakses pada tanggal 10 April 2019.

${ }_{9}^{9}$ Iswi Hariyani dan Cita Yustisia Serfiani, 2018, Penyelesaian Sengketa Bisnis, PT Gramedia Pustaka Utama, Jakarta, h.27. 
3.1.2 Upaya hukum yang dapat ditempuh oleh konsumen antara lain, Penyelesaian pada BPSK yang melalui 3 tahapan yaitu: konsiliasi, mediasi dan arbitraase. Upaya selanjutnya konsumen dapat melaporkan kepada BPOM yang dimana BPOM menyediakan Unit Layanan Pengaduan Konsumen sebagai wadah dan sarana untuk menampung masalah yang ihadapi oleh konsumen. Apabila yang ditempuh pada tahap sebelumnya pada BPSK tidak berhasil maka konsumen dapat mengajukan gugatan kepada peradilan ditempat kedudukan konsumen berada.

\subsection{Saran}

3.2.1 Dalam memproduksi produk kosmetika pelaku usaha diharuskan memenuhi standar produksi kosmetika yang sudah ditetapkan oleh Undang-Undang, dengan penggunaan komposisi yang tepat, pecantuman tanggal kadaluarsa dan mendaftarkan produk kosmetika pada Badan Pengawas Obat dan Makanan. Konsumen sebagai pengguna kosmetika juga diharuskan berhati-hati dan selektif sebelum membeli produk kosmetik, agar tidak rugikan apabila di waktu yang akan datang terjadi hal-hal yang tidak sesuai dalam perjanjnian jual beli kosmetika.

Perlu adanya edukasi konsumen yang termasuk kedalam hal yang seharusnya dilaksanakanoleh konsumen Karenna factor rendahnya tingkat pengetahuan masyarakat indonesia yanglambat laun akan berlanjut pada tahap tingkat kesadaran masyarakat atau konsumen dalam memahami suatu produk barang dan atau jasa layak atau tidak diproduksi. 
3.2.2 Dalam mewujudkan keamanan dalam penyebaran Atau penggunaan suatu produk peran lembaga Pemerintah perlu ditingkatkan, salah satunya peran BPOM dalam pengawasan Pre marketing maupun post marketing suatu produk, serta pengawasan yang lebih ketat melalui HACCP dimana pengawasan ini dimulai dari proses produksi sampai produk tersebut beredar di pasaran

\section{DAFTAR PUSTAKA}

\section{Buku:}

Celina Tri Iswi Kristiyanti, 2011, Hukum Perlindungan Konsumen, Sinar Grafika, Jakarta.

Gunawan Widjaja, Ahmad Yani, 2000, "Hukum Perlindungan Konsumen", Gramedia Pustaka Utama, Jakarta

I Made Widnyana, 2014, Alternatif Penyelesaian Sengketa Dan Arbitrase, Fikahati Aneska, Jakarta.

Sidhiarta, 2004, Hukum Perlindungan Konsumen Indonesia, PT.Grasindo Edisi Revisi, Jakarta.

Soerjono Soekanto, 2010, Pengantar Penelitian Hukum, UI Press, Jakarta.

Iswi Hariyani dan Cita Yustisia Serfiani, 2018, Penyelesaian Sengketa Bisnis, PT Gramedia Pustaka Utama, Jakarta.

\section{Peraturan Perundang-Undangan}

Republik Indonesia, 1999, Undang-Undang Nomor 8 Tahun 1999 Tentang Perlindungan Konsumen, Lembaran Negara Republik Indonesia Tahun 1999, Nomor 42, Sekretariat Negara, Jakarta.

Peraturan Presiden Republik Indonesia Nomor 80 Tahun 2017 Tentang Badan Pengawas Obat Dan Makanan, 
Lembaran Negara Republik Indonesia Tahun 2017 Nomor 180.

Peraturan Menteri Kesehatan Republik Indonesia Nomor 1175 Tentang Izin Produksi Kosmetika, Berita Negara Republik Indonesia Tahun 2010 Nomor 396.

\section{Jurnal Ilmiah}

Ali Mansyur, Irsan Rahman, Penegajjan Hukum Perlindungan Konsumen Sebagai Upaya Peningkatan Mutu Produksi Nasional, jurnal penelitian Universitas Islam Sultan Agung, Volume 11 Nomor 1 Januari-April Tahun 2015, URL:https://online-jurnalunisulla.ac.id.

Putu Januaryanti Pande, "Perlindungan Konsumen Terhadap Produk Kosmetik Impor Yang Tidak Terdaftar", jurnal Magister Hukum Udayana, Volume 6 Nomor 1

Tahun 2017,DOI:https:/ /doi.org/10.24843/JMHU.2017.v05.i 04.p02,URL:https://ojs.unud.ac.id, pada tanggal 10 April 2019.

Novitasari, “Tinjauan Yuridis Pembatasan Jangka Waktu Penundaan Kewajiban Pembayaran Utang Terhadap Debitor", jurnal Magister Hukum Udayana, Volume 39. Nomor 2 Agustus 2017, DOI:https//doi.org/1024843/KP2017.v39.i02.p02, URL:https://ijs.unud.ac.id diakses pada tanggal 10 April 2019. 
